NOAA

National Marine

Fishery Bulletin

Spencer F. Baird

Fisheries Service

$\therefore$ established 1881 ๙

Abstract-Bottom trawling has been shown to affect the seafloor and associated biological communities around the world. Considerably less is known about the dynamics of impacts to structural attributes of fish habitat, particularly in unconsolidated sandy sediments of the continental shelf. We collaborated with commercial fishermen to conduct experimental trawls, with the type of small-footrope trawl required for trawling on the continental shelf, along the $170-\mathrm{m}$ isobath in an area off Morro Bay in central California. The bottom trawling intensity we applied was based on the historical range of fishing effort in the study area and included low-intensity and high-intensity treatments. A remotely operated vehicle was used to collect continuous video and still photographs in trawled and in untrawled control plots, before trawling and at 2 weeks, 6 months, and 1 year after trawling. Scour marks from the heavy doors of the trawl were observed in the seafloor and persisted for at least a year. Although data extracted from the collected imagery showed some smoothing of the seafloor in trawled plots, the minimal differences between trawled and control plots in microtopographic structure on the seafloor were statistically significant only during one sampling period. Further, there were no significant differences between trawled and untrawled plots with respect to structure-forming invertebrates (e.g., sea whips) and mobile invertebrates (e.g., sea stars). The results of our study, part of ongoing efforts to understand and manage fishing impacts, indicate that bottom trawling with a small-footrope gear may have limited effects in some sand habitats.

Manuscript submitted 28 August 2013. Manuscript accepted 12 December 2014. Fish. Bull. 113:82-96 (2015).

doi: 10.7755/FB.113.1.8

The views and opinions expressed or implied in this article are those of the author (or authors) and do not necessarily reflect the position of the National Marine Fisheries Service, NOAA.

\title{
Ecological effects of bottom trawling on the structural attributes of fish habitat in unconsolidated sediments along the central California outer continental shelf
}

\author{
James Lindholm 1 \\ Mary Gleason ${ }^{2}$ \\ Donna Kline ${ }^{1}$ \\ Larissa Clary ${ }^{1}$ \\ Steve Rienecke ${ }^{2}$ \\ Alli Cramer ${ }^{1}$ \\ Marc Los Huertos ${ }^{3}$ \\ Email address for contact author: jlindholm@csumb.edu \\ 1 Institute for Applied Marine Ecology \\ California State University Monterey Bay \\ 100 Campus Center \\ Seaside, California 93955 \\ 2 The Nature Conservancy \\ 99 Pacific Street, Suite 200G \\ Monterey, California 93940 \\ ${ }^{3}$ Environmental Analysis Program \\ Pomona College \\ 185 East 6th Street \\ Claremont, California 91711
}

The ecological effects of bottom trawling on continental shelves have been documented in several regions of the world (see reviews in Dayton et al., 1995; Kaiser et al., 1998; Watling and Norse, 1998; Auster and Langton, 1999; NRC, 2002). These effects include overfishing (NRC, 1999; Jackson et al., 2001) and bycatch (Alverson et al., 1994; De Alteris et al., 2000; Machias et al., 2001; Anderson and Clark, 2003), as well as impacts to structural attributes of the seafloor (Auster et al., 1996; Lindholm et al., 2004). Indeed, bottom trawling has been described as the most significant impact on marine ecosystems below the effective depth of storm penetration (Dayton et al., 1995; Watling and Norse, 1998; NRC, 2002).

In the context of impacts to the seafloor, it has been established that bottom trawling can smooth bedforms (Hall, 1994; Schwinghamer et al., 1998), remove structure-forming invertebrate fauna (the bodies of such organisms provide habitat structure) (Auster et al., 1996; Collie et al., 1997; Kaiser et al., 2000; Koslow et al., 2001), and remove structure-building organisms that create habitat (such as depressions in the sediment), as a result of their normal behavior (Auster and Langton, 1999). Bedforms and habitat features formed or created by organisms are used by fishes at a variety of life history stages as refugia from predators and bottom currents (Auster et al., 1991; Auster and Langton, 1999; Stoner and Titgen, 2003).

Observations of the use of sandwave habitats on Georges Bank and 
in the western Gulf of Maine by silver hake (Merluccius bilinearis) indicate a strong correlation between individual fish size and sand-wave period; smaller fishes use smaller sand waves (Auster et al., 2003a). Acadian redfish (Sebastes fasciatus) have been seen to have ontogenetic shifts from physical attributes (piled boulder reefs) of the seafloor at early life history stages to structure-forming invertebrates (erect Cerianthid anemones) found in adjacent soft sediment habitats at late-juvenile stages (Auster et al., 2003b). Sea pens (of the order Pennatulacea) have been shown to harbor fish larvae, potentially playing an important role in the early life history of some redfishes (Sebastes spp.) (Baillon et al., 2012). Sea whips have also been observed to harbor dense aggregations of Pacific ocean perch ( $S e$ bastes alutus) in the Bering Sea (Brodeur, 2001). In California, Hallenbeck et al. (2012), using a remotely operated vehicle (ROV), found higher densities of small fishes and invertebrate fauna inside naturally occurring rippled scour depressions than densities in low-relief habitats outside these depressions. These features are now known to occur across the continental shelf of California in sandy substrates (Davis et al., 2013). Further, structural attributes of the seafloor have been shown to enhance survival of postsettlement demersal fishes, both in laboratory experiments (Lindholm et al., 1999) and in field studies (Tupper and Boutilier, 1995).

Literature on the ecological effects of bottom trawling has grown over the past twenty years. There is some evidence that low-relief sandy environments recover more quickly after cessation of trawling than higher-relief hard substrates and the fauna associated them (NRC, 2002; Barnes and Thomas, 2005). The dynamics of recovery from trawling within soft sediments are less clear. Studies in which bottom grabs were used to sample organisms in unconsolidated sediments have revealed a measurable impact from trawling on an infaunal community in the North Sea from a single pass of a beam trawl, even in an environment that had been trawled heavily for decades (Reiss et al., 2009), but in a study in South Africa, no measurable impacts of additional trawling to the epifaunal community in a continuously trawled area (Atkinson et al., 2011). On Georges Bank, Lindholm et al. (2004) observed trawling impacts to sand habitats below the $60-\mathrm{m}$ isobath in imagery collected with a video drift camera, but no impact was evident at depths shallower than $60 \mathrm{~m}$ in sand habitats, where grain sizes were similar to those in the deeper habitats where regular storm and tidal currents re-sorted the sediment. Important questions remain, particularly with respect to the effects of bottom trawling on the structural attributes of seafloor habitat in unconsolidated sediments.

Insight into the ecological effects of bottom trawling in unconsolidated sandy sediments is particularly important for California, where more than $80 \%$ of the continental shelf comprises sand (Allen et al., 2006) and bottom trawling has been an important component of the groundfish fishery. However, a limitation com- mon to the few existing studies of impacts of trawling along the West Coast of the United States (Engel and Kvitek, 1998; Freese et al., 1999; McConnaughey et al., 2000; Hixon and Tissot, 2007; de Marignac et al., 2009) was the fact that trawling effort was not controlled as part of these studies. These studies, although instructive, have been either 1) snapshots based on data collected after trawling, 2) studies with little knowledge of the intensity of trawling effort in the area studied, or 3) both. Available historical data on the distribution of trawling rarely exist, especially with the level of precision in georeferenced track lines that are critical for the accurate quantification of impacts to the seafloor; most available historical data occur as averaged estimates of trawling intensity across large areas (Bellman et al., 2005; Mason et al., 2012).

California has a long history of bottom trawling, and many ports have relied on landings of trawl-caught groundfishes. However, because of various regulatory and socioeconomic factors, trawling effort has shifted spatially and has diminished in recent years (Bellman et. al., 2005; Mason et. al., 2012). Regulations on the design of bottom-trawl gear have resulted in much of the effort shifting away from rocky habitats (Bellman et al., 2005). One regulation in particular restricted the diameter of trawl footrope gear that was allowed for use along the continental shelf. This regulation, enacted by the Pacific Fishery Management Council in 2000, required trawl vessels to use small-footrope gear $(\leq 20$ $\mathrm{cm}$ in diameter) along the continental shelf, therefore, inhibiting the use of large-footrope gear that can pass over rocky terrain (Dalton, 1999). The level of trawling effort (number of active trawl permits) has also been reduced over the last decade because of a federal trawl buy back, and private purchase of trawl permits in the Central Coast (Gleason et al., 2009). The trawl fishery recently transitioned to an individual transferable quota (ITQ) system, and there is increasing use of nontrawl fixed gear that produces consistently higher prices for groundfishes and is intended to reduce bycatch of overfished species. However, trawling is still the primary way to catch flatfish and remains an important component of California fisheries (Hilborn et al., 2012).

The type and intensity of impact of bottom trawling on the seafloor and associated ecological communities are significant for effective management of trawling activities. As of this writing, state and federal management agencies have implemented closures of broad areas; these closures have limited the current trawling but also have constrained commercial fisheries and reduced landings and local seafood supply (Hilborn et al., 2012). A ban on trawling in California state waters, with the exception of some halibut trawl grounds, was implemented through state legislation that was enacted in 2004 (Calif. State Legislature, 2004). The Rockfish Conservation Area (RCA), established from 2002 to 2007 and extending from northern Washington to southern California, excludes trawling to help re- 
building efforts for overfished stocks and has resulted in displacement of some trawling effort (Bellman et al., 2005). Federal closures for trawl fishing in additional areas were established in 2006 to protect essential fish habitat (Copps et al., 2008; Gleason et al., 2013). Together, these closures to trawling protect $61 \%$ of shelf and slope habitat from bottom trawling in central California, between Point Conception and Point Reyes from the shore to a depth of $2000 \mathrm{~m}$ ).

In this study, we collaborated with members of the commercial fishing industry to conduct experimental trawling with small-footrope gear at known intensities in the unconsolidated sediments of the outer continental shelf off Point Buchon and Morro Bay in central California. This directed trawling allowed us to quantify, with a high degree of confidence, the impacts to physical and biological attributes of fish habitat in the study area.

\section{Materials and methods}

\section{Data collection}

The primary study area was located on the outer continental shelf off Point Buchon and Morro Bay (Fig. 1). This study area was selected after discussions with members of the commercial fishing industry in Morro Bay and was situated immediately shoreward of the federal RCA at the shelf-slope break in a location that was historically trawled for flatfish, such as the petrale sole (Eopsetta jordani) and Dover sole (Microstomus pacificus). The study area had not been trawled commercially since before 2000, according to vessel monitoring system data (Mason'1 Mason et al., 2012). Prospecting with an ROV in 2008 and multibeam sonar in 2009 revealed that the area comprises low-relief, unconsolidated sediments. Our study was conducted between 2009 and 2012; in 2012, additional surveys were conducted with an ROV along transects to the north and south of the study area to compare different substrates and biological communities at other locations along the shelf (Fig. 1).

Along the $170-\mathrm{m}$ isobath, 8 paired study plots were identified (Fig. 1). Each plot measured approximately $1000 \mathrm{~m}$ by $300 \mathrm{~m}$, and $500 \mathrm{~m}$ separated each adjacent plot. Plots were numbered from 1 to 8 consecutively from north to south; plots $3,4,7$, and 8 were experimentally trawled plots, and plots 1, 2, 5 and 6 were untrawled (or control) plots.

\section{Experimental trawling}

All trawling activities were conducted aboard FV South Bay, a 16.8-m trawler that operated from Morro Bay. The South Bay was equipped with a bottom trawl that had a small footrope, in accordance with gear require-

\footnotetext{
${ }^{1}$ Mason, J. 2008. Personal commun. Pacific Fisheries Environmental Laboratory, Southwest Fisheries Science Center, National Marine Fisheries Service, NOAA, Pacific Grove, CA 93950.
}

ments under federal regulations for trawling shoreward of the RCA. The trawl design consisted of a 2-bridle trawl with a fishing circle of 300 meshes and a mesh size of $11.6 \mathrm{~cm}$. The funnel tapered down to the codend at a 2:1 cutting ratio, and the mesh size at the codend was $11.4 \mathrm{~cm}$. The footrope was configured with "mudgear" discs that measured 20.3 and $10.2 \mathrm{~cm}$ in diameter. The larger 20.3-cm-diameter discs were spaced evenly along the footrope at 1-m intervals, allowing the smaller 10.2 -cm-diameter discs to ride above the seafloor. The net was held open by trawl doors, each measuring 1.1 by $1.4 \mathrm{~m}$ and weighing approximately 315 kg. Trawling operations were conducted at a speed of 2.1 knots, which is the speed typically used to harvest most flatfishes and soles (Bothidae and Pleuronectidae) in the federal groundfish fishery. An exception to this typical speed is that speeds of 3.0-4.0 knots are used to harvest California halibut (Paralichthys californicus) in the state-managed fishery for that particular species. At the speed used for this study, the trawl doors spread the net width to $55 \mathrm{~m}$ and the net height to $2.4 \mathrm{~m}$.

Experimental trawling operations were divided into 2 treatments according to intensity of effort: low intensity and high intensity. The 2 treatments were designed to broadly reflect the range of effort applied historically to the seafloor in the study area, on the basis of published records (Mason et al., 2012) and unpublished data collected by NOAA Fisheries $\left(\right.$ Mason $\left.^{1}\right)$. The number of trawl passes per treatment was calculated by using the width of the study plots and the width of the trawl doors on the seafloor when underway. The lowintensity treatment (October 2009) featured enough passes through the study plots to ensure that every square meter of each plot was trawled 3 times. The high-intensity treatment (October 2010) doubled that effort on the same plots so that each plot was impacted an additional 5 times, for a total of 8 passes. For logistical reasons, the high-intensity trawling effort was applied to the previously trawled plots and, therefore, reflects 2 years of directed trawling. To minimize the number of times the trawl gear was deployed and recovered during each treatment and to avoid accidentally trawling in control plots, adjacent plots were paired such that the trawl would remain on the seafloor from the beginning of plot 3 to the end of plot 4 , and the same protocol followed at plots 7 and 8 (Fig. 1).

\section{Imagery collection}

Video and still imagery of the seafloor were collected with a Vector L4 ROV (Deep Ocean Engineering, Inc., San Jose, CA) equipped with 3 georeferenced cameras (forward-looking video, down-looking video, and digital still camera), 2 quartz halogen and 2 hydrargyrum medium-arc iodide lights, paired forward- and downlooking lasers, and a strobe for enhancement of still photographs. The ROV was also equipped with an altimeter and forward-facing multibeam sonar. The position of the ROV on the seafloor was maintained with 


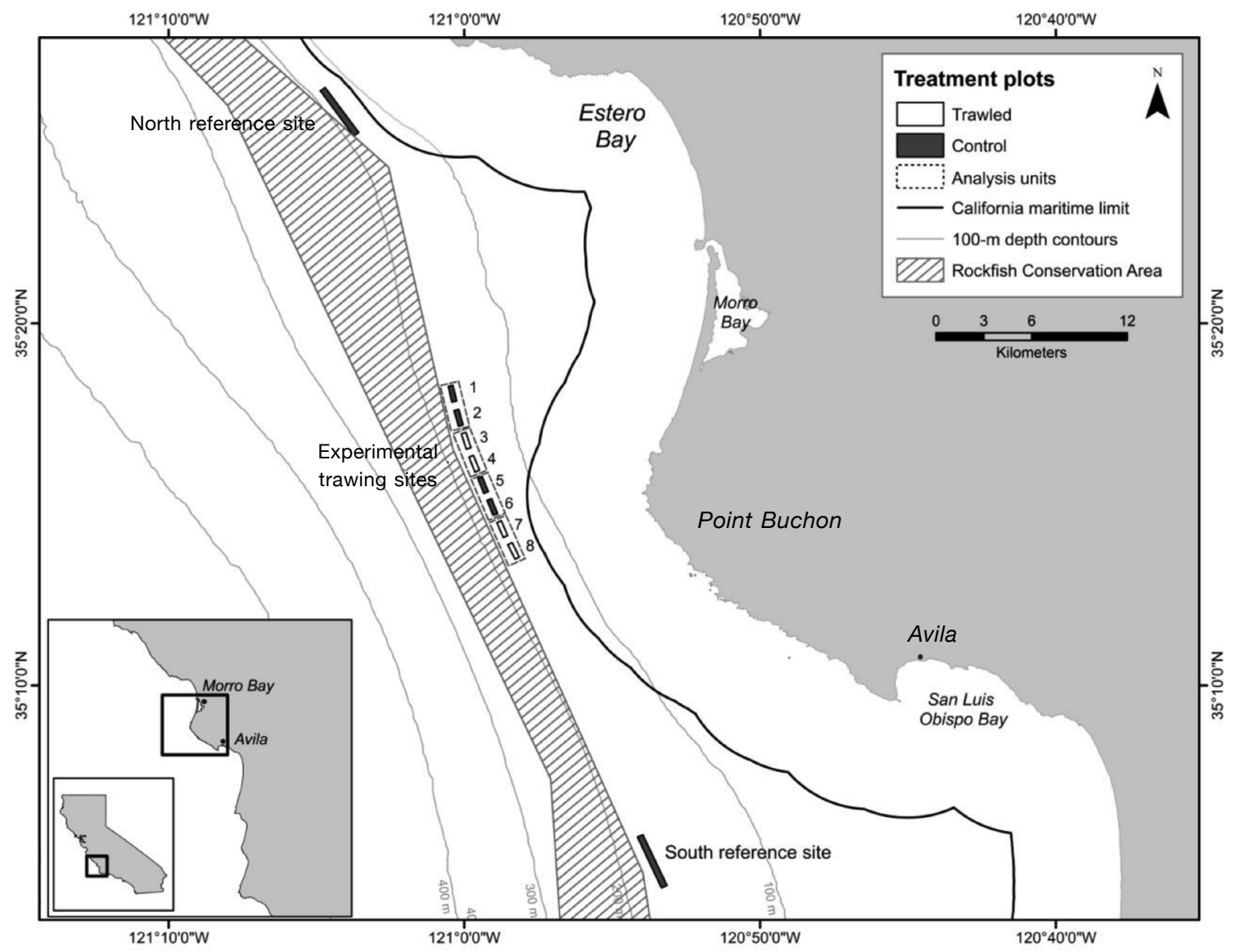

Figure 1

Map of the study area in waters off Point Buchon and Morro Bay in central California, where 4 control plots (black) and 4 trawled plots (white) were sampled between 2009 and 2012 and grouped into 4 analysis units (dotted lines). North and south reference sites (shown) were sampled in May 2012. Also included are the state waters boundary (black line) and the extent of the Rockfish Conservation Area (hatched area).

a Trackpoint 3 acoustic positioning system (EdgeTech, West Wareham, MA) and the resulting coordinates were logged into Hypack navigational software, vers. 2010 (Hypack, Inc., Middletown, CT). The ROV was "flown" over the seafloor at a mean altitude of $0.8 \mathrm{~m}$ and a speed of approximately 0.6 knots.

A before-after-control-impact (BACI) sampling design was employed for these visual surveys. Surveys of the 8 study plots were conducted with the ROV in September 2009, immediately before the low-intensity trawling treatment. Subsequent ROV surveys were conducted 2-weeks after trawling (November 2009), 6 months after trawling (April 2010), and 1 year after trawling (September 2010). Visual surveys were again conducted with the ROV at 2-weeks (November 2010), 6 months (May 2011), 1 year (September 2011), and 1.5 years (May 2012) after the high-intensity trawling. During the final ROV surveys in May 2012, 3 additional transects were surveyed at similar depths to the north and south of the study area (Fig. 1) to explore the extent to which the substrate and biological com- munity in the study area was reflective of the broader region of the central California coast.

During each sampling period, 3 transects in each study plot were surveyed with an ROV. Each ROV transect measured approximately $300 \mathrm{~m}$ in length (20 min in duration) as determined by species and habitat accumulation curves plotted from data collected previously in soft sediment communities (Lindholm et al., 2004, 2009; de Marignac et al., 2009) and from a review of preliminary data collected in the study area in the fall of 2008. Surveys were initiated on transects randomly from a set of pre-existing starting points located at either the northwest or southeast ends of each study plot. Determination of the starting point of a plot depended on local conditions at the time of the dive so that any effect of currents and wind was minimized. After the starting point of a plot was determined, a random number generator selected a starting point from among twenty potential points, and the ROV subsequently followed the $170-\mathrm{m}$ isobath across the long axis of the study plot. 
Digital still photographs were taken at 1-min intervals along each transect for a minimum of 20 photographs. Each still photograph covered an area of approximately $0.42 \mathrm{~m}^{2}$. Paired, parallel, down-looking lasers (spaced $10 \mathrm{~cm}$ apart on the ROV) provided a consistent reference for still photographs to maintain constancy in area of coverage for each image and to size individual organisms where possible. Still photographs were used to assess the primary metrics of the study, namely 1) the percent cover of microtopographic features, meaning the proportion of the seafloor that had an elevation, burrow, or other microtopographic feature, 2) density of structure-forming macro-invertebrates, and 3) density of selected mobile macro-invertebrates.

From our observations across multiple ROV surveys, we determined that the microtopographic complexity in the unconsolidated sandy sediments at the study depths primarily resulted from bioturbation. Bioturbation in this context refers to deviations from the plane of the sediment-water interface (such as ridges and mounds, burrows and hole) created by the movement of organisms such as sea stars and fishes or organisms such as mud urchins through the upper centimeters of the sediment. Small features that result from bioturbation can serve as habitat for demersal fishes from a variety of species, including many flatfishes found in the study area. Digital still photographs were used to quantify the spatial extent of microtopographic features (i.e., bioturbation) in each of the 8 study plots. The percent area covered was quantified for each still photograph with a digitally rendered grid that was 5 by $5 \mathrm{~cm}$ and was superimposed over each photograph. Any cell in which a microtopographic feature was evident was counted.

Digital still photographs also were used to quantify the density of benthic invertebrate species in each study plot. Structure-forming organisms (such as those found in the study area, primarily sea pens, sea whips, and anemones) are erect, mostly sedentary creatures that extend above the plane of the sediment and provide potential habitat structure for fishes and mobile invertebrates. Mobile organisms, including crabs, urchins, and sea stars, move along and across the plane of the sediment, providing transient habitat themselves (e.g., for small fish seeking cover adjacent to larger sea stars) and altering the sediment itself, as described previously. Densities of both structureforming and mobile invertebrates were extracted from digital still photographs. Every organism that occurred in still photographs was counted and identified to the lowest taxonomic level possible and then grouped by taxon or mobility for analyses.

\section{Data analyses}

Although a BACI sampling design was planned (similar to the one used by Pitcher et al., 2009) with 8 randomly distributed plots, the limitations, described previously, in the distribution of trawling effort across those plots required that we alter our analytical approach. To optimize our ability to detect statistical differences among paired plots and across years and to reduce the probability of a type-II error, we randomly selected 50 photographs from each of 4 pairs of adjacent plots for each treatment (identified as analysis units in Fig. 1) so that independent samples would be distributed across the entire study area and across time. This practice effectively reduced the number of replicates for each treatment from 4 plots to 2 pairs of adjacent plots and allowed for a greatly improved number of samples $(N)$, when compared with a transect-based approach: $N=1600$ for treatment-wide analyses, and $N=200$ for year-to-year comparisons. This approach also reduced the effect of spatial autocorrelation in data collected along sequential transects and eliminated any inflated statistical significance due to psuedoreplication (Hurlbert, 1984).

We used the 2-proportion $Z$-test to determine whether the hypothesized difference between population proportions (arcsine transformed) in microtopographic structure varied significantly between trawled and control plots and within treatments (high-intensity or lowintensity trawling effort) over time. $T$-tests were used to test for any differences in the densities of structureforming macroinvertebrates and mobile macroinvertebrates between trawled and control plots and within treatments over time. Post-hoc power analyses were conducted with the statistical program $\mathrm{R}$, vers. 3.1.0 (R Core Team, 2014) on the $Z$-test and $t$-tests for the 3 primary metrics to evaluate the power of each test to detect significant differences, particularly given the low densities observed for sessile, structure-forming invertebrates and for mobile invertebrates.

\section{Results}

From September 2009 to May 2012, ROV surveys were completed along 297 transects in the study area, and 6200 still photographs were taken on transects (an additional 11,000 photographs were taken to support species identifications and to capture unique features). From those still photographs, we extracted data on 38 invertebrate species from 5 phyla-anthozoans (10), echinoderms (11), molluscs (11), crustaceans (3), and annelids (3). Polychaete worms (Chloeia pinnata) were numerically dominant, followed closely by several species of brittle stars (phylum Echinodermata: class Ophiuroidea), all of which occurred on the surface of the sediment in dense but spatially and temporally variable patches.

\section{Temporal and spatial variability}

Although overall density of these observed species was low (fractions of individuals per square meter) in the study area, temporal variability in the densities of selected invertebrate taxa was considerable across sam- 


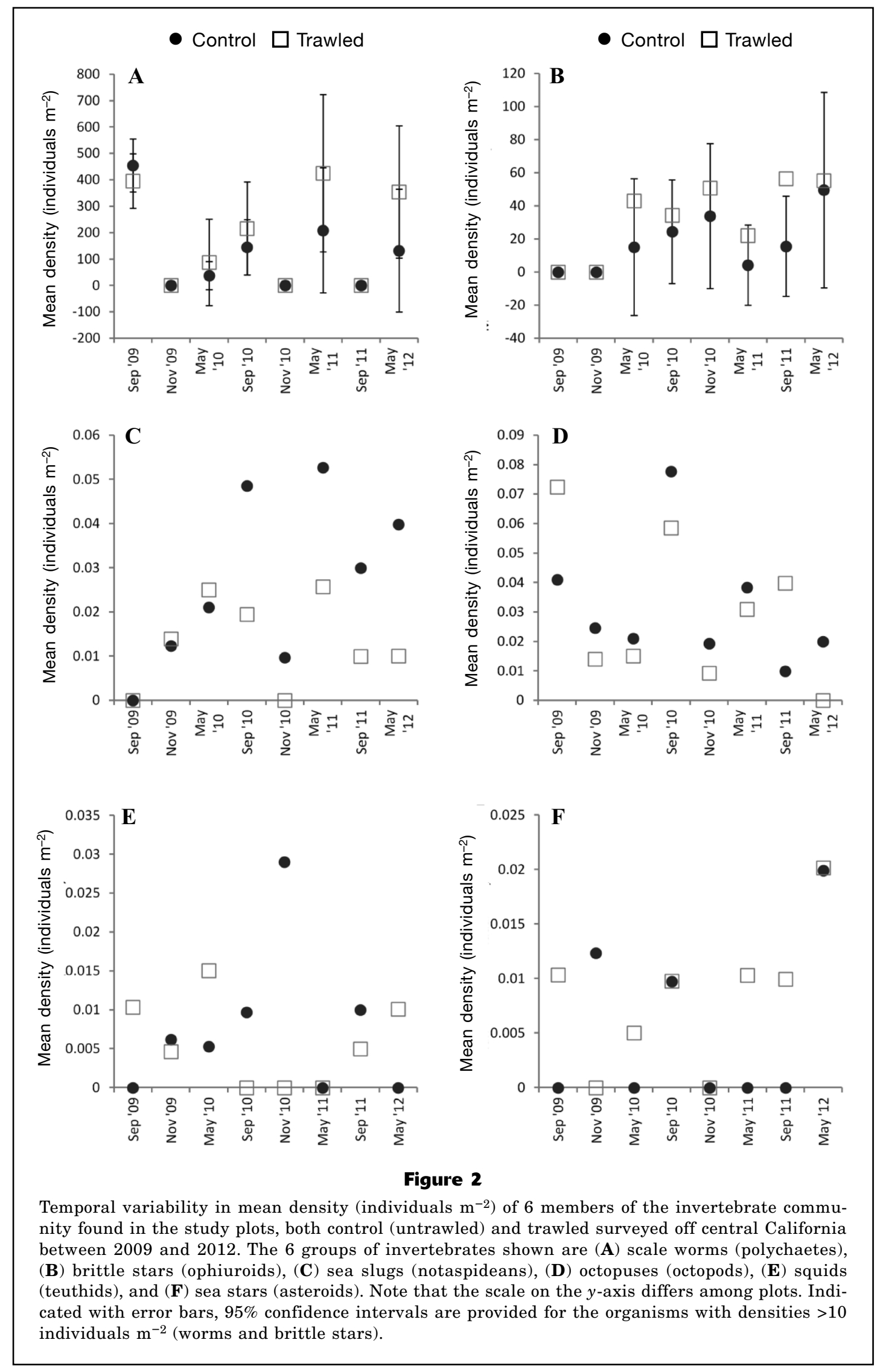



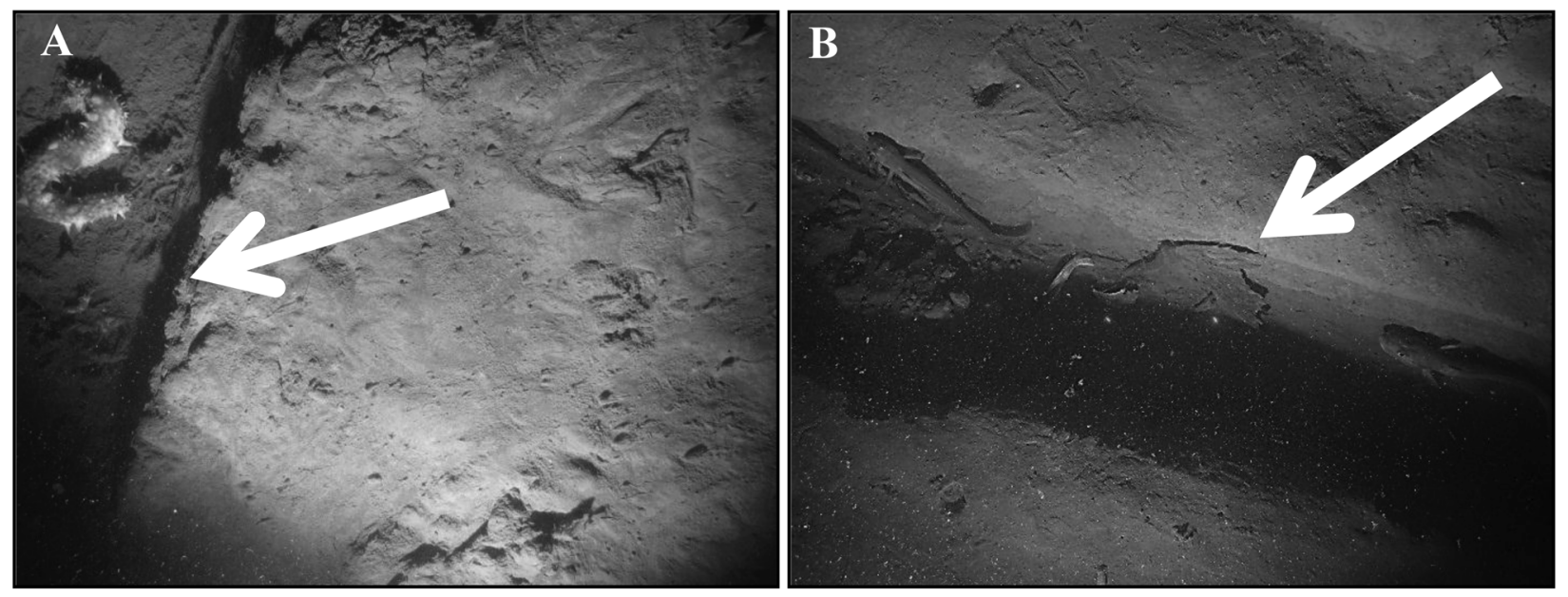

Figure 3

Photographs of scour marks created by doors of the bottom trawl used in this study conducted off central California. Images were taken (A) in November 2009, immediately after low-intensity trawling, and (B) in September 2010, 1 year after low-intensity trawling.

pling periods and seasons (Figs. 2, A-F). The densities of polychaete worms (Fig. 2A) peaked during 3 separate sampling periods during 2 separate seasons; the largest peak (480 individuals $\mathrm{m}^{-2}$ ) occurred in September 2009, followed by smaller peaks in May 2011 (430 individuals $\mathrm{m}-2$ ) and May 2012 (390 individuals $\mathrm{m}-2$ ). No polychaetes were observed in either November 2009 or November 2010. Occurrence of brittle stars (Fig. 2B) was observed at much lower densities. For example, absent from the study area in September and November 2009 , brittle stars were present during every other sampling period, peaking at 60 individuals $\mathrm{m}-2$ in September 2011. Other organisms, including notaspideans (Fig. 2C), octopods (Fig. 2D), teuthids (Fig. 2E), and asteroids (Fig. 2F) were present in very small, although variable, densities over the course of our study.

In the broader study area, the north reference site (Fig. 1) had an assemblage of sessile invertebrates that was similar to the assemblage in the primary study area, including sea whips (Halipteris spp.), sea pens (Ptilosarcus gurneyi, Pennatula spp., and Stylatula spp.), and anemones (Halcampidae, Urticina spp., and Pachycerianthus fimbriatus). The south reference site had invertebrates that were more mobile, primarily ocean shrimp (Pandalus jordani), that were rarely observed in the study plots. However, it should be noted that the amount of recent trawling effort in the north and south reference sites was unknown.

\section{Low-intensity trawling}

Trawl doors can create scour marks (or troughs) in the sediment as they are towed along the bottom of the seafloor. Scour marks from the low-intensity trawling effort were clearly evident in the sediment immediately after the directed trawling (Fig. 3A) and were still present 1 year after trawling in September 2010 (Fig. 3B). Demersal fishes, mobile invertebrates, and drift kelp were all observed in and immediately adjacent to these scour marks.

The mean percent cover of microtopographic features was similar between the trawled and control plots in September 2009 before the directed trawling, at $75 \%$ and $72 \%$, respectively (Fig. $4 \mathrm{~A}$ ). Immediately following the low-intensity trawling treatment, the percent cover of microtopographic features in control and trawled plots diverged but did not differ statistically $(Z=0.109, P=0.460)$. The mean percent cover of microtopographic features in the trawled plots declined by $15 \%$. Interestingly, the percent cover also declined after trawling in the control plots, although by an amount (9\%) lower than the decrease in the trawled plots. The small but insignificant difference in complexity $(Z=0.096, P=0.464)$ between trawled and control plots persisted at 6 months after trawling, but values in both types of plots stabilized. In August 2010, at 1 year after trawling, the mean percent cover of microtopographic features declined in both groups of plots over the 6-month period (15\% and $17 \%$ in control and trawled plots, respectively) but were not significantly different $(Z=0.156, P=0.440)$. The cumulative decline in mean percent cover at 1 year after trawling was $-24 \%$ and $-31 \%$ in control and trawled plots, respectively.

The densities of both sessile, structure-forming (Fig. 4B) and mobile (Fig. 4C) macro-invertebrates were very low in both trawled and control plots before and after 


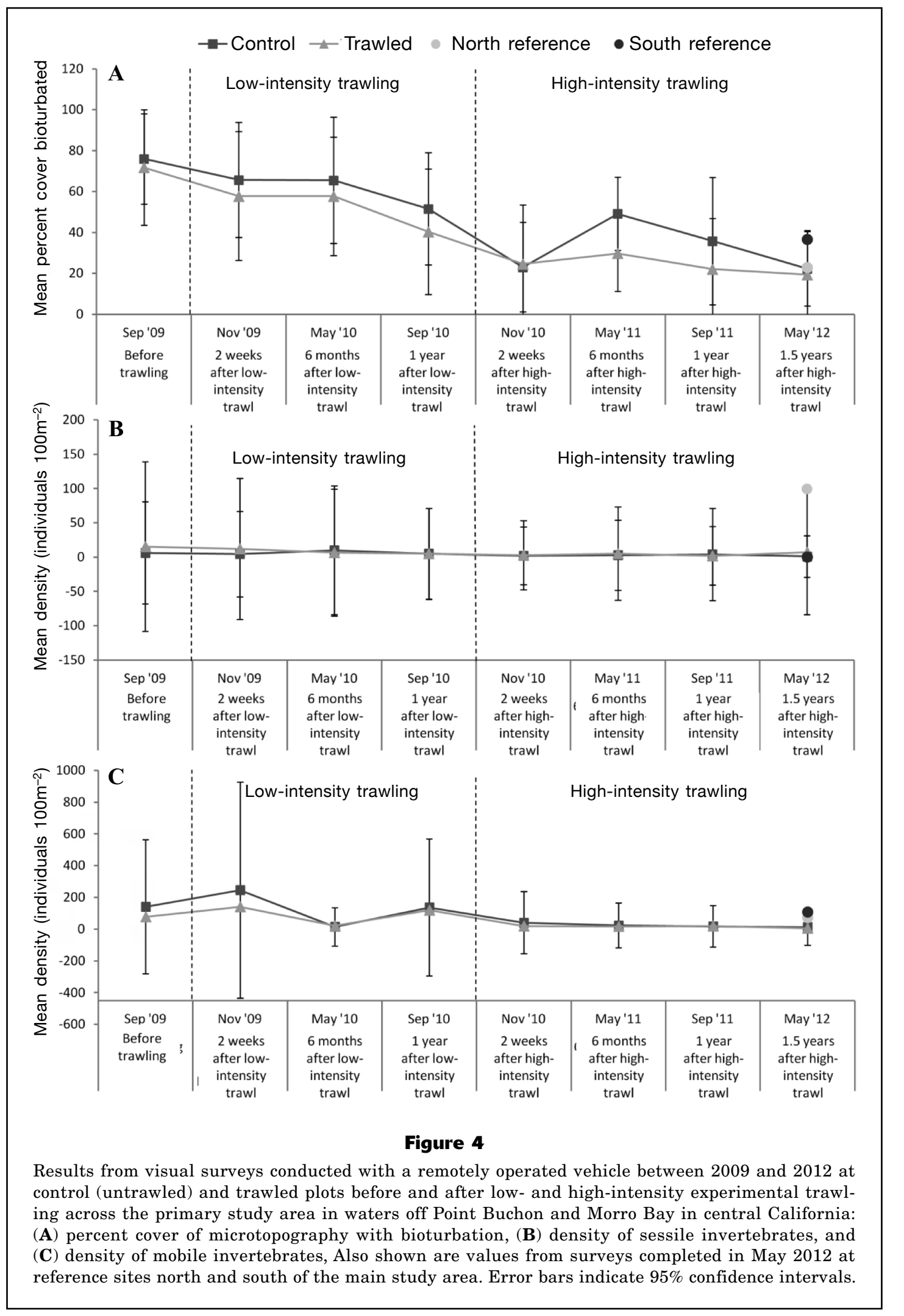


low-intensity trawling. The densities of sessile invertebrates, which peaked at 2.3 individuals $100 \mathrm{~m}-2$, were not significantly different between trawled and control plots at any point over the study period. The densities of mobile macro-invertebrates were higher, peaking at 220 individuals $100 \mathrm{~m}^{-2}$ but did not differ significantly between trawled and control plots after low-intensity trawling activities.

\section{High-intensity trawling}

Scour marks were immediately visible on the substrate during visual surveys conducted 2 weeks after highintensity trawling-an observation consistent with those of the condition of the seafloor after low-intensity trawling. The mean percent cover of microtopographic complexity features (Fig. 4A) was not significantly different between the trawled and untrawled plots in August 2010, 1 year after low-intensity trawling and approximately one month before the directed trawling in the same study plots at a higher intensity. Immediately after high-intensity trawling, the mean percent cover microtopographic features in both control and trawled plots declined precipitously, $27 \%$ and $25 \%$ respectively, but did not differ statistically $(Z=0.015, P=0.496)$.

However, in May 2011, at 6 months after high-intensity trawling, the mean percent cover of microtopographic features had increased in both trawled and control plots, and a significant increase of $24 \%$ in the control plots versus $4 \%$ in the trawled plots $(Z=2.802$, $P=0.003)$. At 1 year after trawling, the mean percent cover had declined again in both types of plots to $37 \%$ in control plots and $27 \%$ in trawled plots and did not differ statistically $(Z=0.675, P=0.251)$. In May 2012, approximately 1.5 years after trawling, mean percent cover had declined further in both control and trawled plots to $22.2 \%$ and $19.4 \%$, respectively. The overall decline in mean percent cover of microtopographic features after the cumulative impact of both low- and high-intensity trawling was $-53.96 \%$ and $-52.43 \%$ in control and trawled plots, respectively.

The densities of both structure-forming (Fig. 4B) and mobile (Fig. 4C) macroinvertebrate organisms continued to be very low in both trawled and control plots after high-intensity trawling. The densities of structure-forming invertebrates, which peaked at 0.026 individuals 100 $\mathrm{m}^{-2}$ in the control plots, were not significantly different between trawled and control plots at any point of the study period. The densities of mobile macroinvertebrates did not differ significantly between trawled and control plots after high-intensity trawling activities.

\section{Power analyses}

The results of power analyses (Fig. 5) for our revised sampling design for both overall comparisons $(N=1600)$ and year-to-year comparisons $(N=200)$ indicated that our ability to detect an impact from trawling on microtopographic structure with the $Z$-test was substan- tial and, therefore, that even a small effect $(0.2$, as per Lipsey, 1990) would be clearly discernible. That high power declined very little with the $t$-tests (Fig. 5) for identification of trawling effects on the densities of both structure-forming and mobile macro-invertebrates.

\section{Discussion}

We aimed to quantify impacts of bottom trawling on the structural attributes of fish habitat in unconsolidated sandy sediments on the continental shelf off central California. The persistence of scour marks from the doors of the small-footrope bottom trawl was the primary impact observed in our study. Some smoothing of microtopographic structure on the seafloor was observed in the trawled plots compared with control plots (as measured by reductions in the percentage of the seafloor that was observed to have bioturbation). However, the minimal differences in microtopographic structure were statistically significant only during one of 8 sampling periods over the course of this study. Further, even with a high statistical power to discern such effects, no impacts from bottom trawling were observed in the densities of sessile, structure-forming invertebrates, declines of which are a common indicator of trawling impacts on fish habitat in other studies worldwide (Auster and Langton, 1999; Kaiser et al., 2002; Barnes and Thomas, 2005; Hiddink et al., 2007). Given the considerable variability observed in the densities of mobile macro invertebrates in the study area, no significant differences attributable to trawling existed between trawled and control plots.

Microtopographic features on the seafloor have been shown to provide habitat for demersal fishes of a variety of species (Auster et al., 1995; Auster et al., 1997; Malatesta and Auster, 1999; Tissot et al., 2006), creating the potential for larger, population-scale impacts from bottom trawling (Lindholm et al., 2001; Rooper et al., 2011). Much of the global literature on the effects of bottom trawling has focused on hard substrates (NRC, 2002) and associated high-relief structural attributes (Freese et al., 1999; Henry et al., 2006; Stone, 2006; Hiddink et al., 2006; Althaus et al., 2009). The comparatively limited structural attributes in lowrelief, unconsolidated sediments (such as sand waves and depressions or burrows) still can provide important refugia for fishes (Auster et al., 1997; Gerstner, 1998; Gerstner and Webb, 1998; Sanchez et al, 2000).

We expected that impacts to the structural attributes of fish habitat, including physical (microtopographic) and biological (densities of structure-forming invertebrate) features would be discernible by a difference between control and trawled plots after low-intensity bottom trawling and that the difference would increase following high-intensity trawling. These predictions were based on our understanding of seafloor impacts from other studies (Auster et al., 1996; Engel and Kvitek, 1998; Hixon and Tissot, 2007; de Marignac et al., 


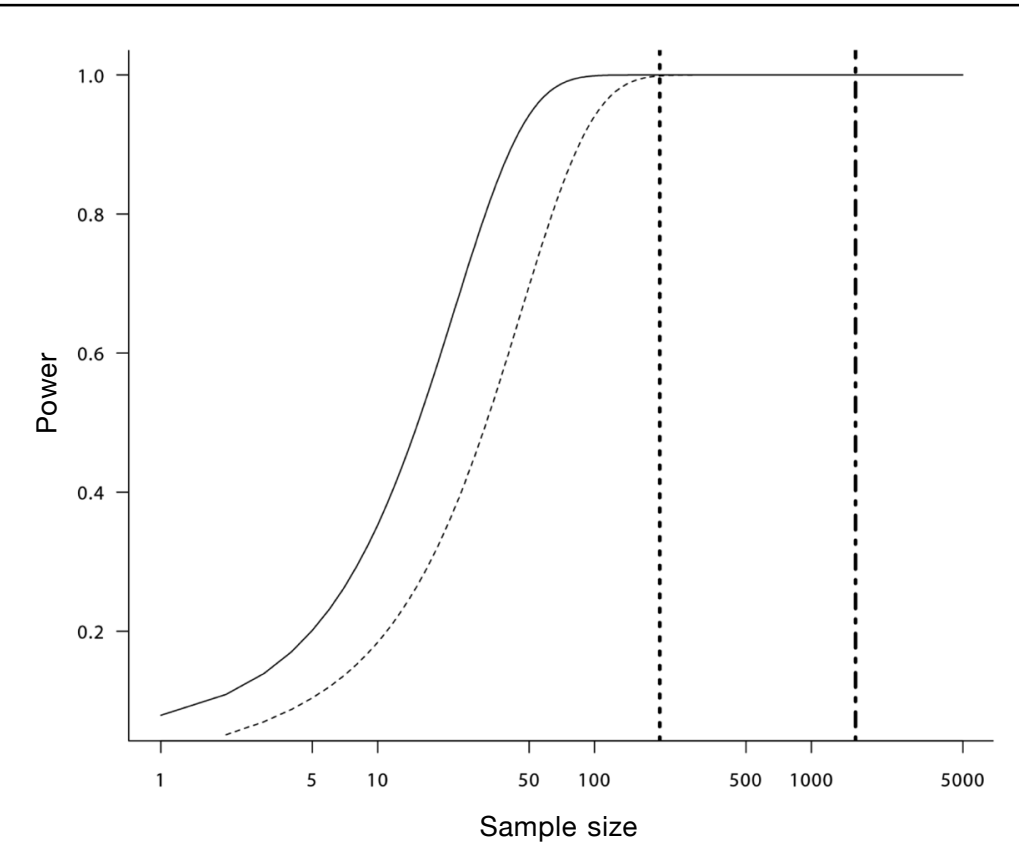

Figure 5

Power curves for $Z$-test conducted on percent cover of microtopographic features (solid curve) and $t$-tests conducted on densities of sessile and mobile invertebrates (dotted curve) from surveys conducted off central California between 2009 and 2012. The $x$-axis was log transformed to resolve differences between the 2 curves. The sample size for all 3 metrics is also provided for overall tests (vertical dashed and dotted lines) and interannual comparisons (vertical dotted line).

2009), global reviews (e.g., Auster and Langton, 1999; Hall, 1994; NRC, 2002; Barnes and Thomas, 2005), and the fact that, at a depth of $170 \mathrm{~m}$, the entire study area was well below the effective depth of storm penetration. For instance, elsewhere along the central coast of California, approximately $375 \mathrm{~km}$ to the north of Morro Bay, de Marignac et al. (2009) conducted a study at similar depths and with similar substrate composition and found that numbers of biogenic mounds and depressions were significantly higher in a recovering area than in an area that continued to be actively trawled.

Yet the expectation of clearly discernible impacts on the seafloor was largely not borne out by the results of our study. After low-intensity trawling, the small but persistent difference in the microtopographic complexity of the seafloor between control and trawled plots was indicative of an impact from bottom trawling. We attributed this difference to the smoothing of habitat features by the trawl footrope as it passed over the bottom of the seafloor (Auster and Langton, 1999), as well as to the removal of the mobile organisms responsible for bioturbation of the sediment (Lohrer et al., 2004; Meysman et al., 2006). However, the difference was not statistically significant in our analyses, despite a high statistical power (Fig. 5). We expected that any impact from trawling would be most pronounced in this study after high-intensity trawling was conducted a year later at the same study plots; however, the trajectories of the differences in microtopographic complexity at the control and trawled plots were even less clear than those for plots where low-intensity trawling was conducted, converging at 2 weeks after trawling, increasing while diverging significantly at 6 months, and then converging again at 1 year after trawling.

Insofar as our trawling activities represented a type-I disturbance, where a relatively small disturbed area is surrounded on one or more sides by undisturbed habitats or organisms (Connell and Keough, 1985), it is possible that the lack of a significant impact to microtopographic structure on the seafloor resulted from the rapid colonization of the patches by bioturbating organisms from surrounding areas. This colonization may also explain why the temporal variation in the data was more pronounced than the spatial variation. Despite the minimal reduction in microtopographic complexity observed in the trawled plots, we did find, on a larger scale, alteration of the seafloor in the form of scour marks from trawl doors that were visible immediately after both low- and high-intensity trawling and that persisted for up to a year after low-intensity trawling. 
The persistence of these tracks is not without precedent (Friedlander et al., 1999), yet the ecological effects of these scour marks, which we estimated to be up to $20 \mathrm{~cm}$ wide and $10 \mathrm{~cm}$ deep and to extend for many meters, are not known. Still, scour marks do represent an alteration of the seafloor. They could positively affect organisms through mobilization of key prey items (Shephard et al., 2009) or creation of additional habitat structure (Kaiser and Spencer, 1994). Conversely, the scour marks could negatively affect organisms depending on the nature and extent of their association with the seafloor and the substrate type.

Our expectations also were not borne out with respect to densities of sessile, structure-forming macroinvertebrates. Biogenic structures on the seafloor have been shown to be important for demersal and benthic fishes at multiple life history stages (Baillon et al., 2012; Auster et al., 2003a). However, in our study, there were no significant differences between control and trawled plots with respect to densities of sessile macroinvertebrates, which were already at relatively low densities at the start of the study. Further, the densities of mobile invertebrates varied considerably over the course of our study but did not differ significantly between levels observed at control and trawled plots with either low- or high-intensity trawling effort. A brief investigation of infaunal organisms conducted as part of this study (Kitaguchi, 2011) also revealed no differences.

Most of the invertebrate groups that we assessed had low densities but showed high spatial and temporal variability. Polychaete worms and ophiuroids were especially patchy and variable in their distributions. Information on the dynamics of organisms in and on unconsolidated sediments of the outer continental shelf off the central California coast continues to be very limited, despite the fact that unconsolidated sediments characterize more than $80 \%$ of the continental shelf in California (Allen et al., 2006). Indeed, the dominant characterization of communities on soft sediments worldwide has been one of patchiness at multiple scales (Morrisey et al., 1992; Oliver et al., 2011), where the distributions of organisms are frequently more diffuse than the distributions of species associated with shallow-water reefs where habitats are more discrete.

With this considerable variability as a backdrop, we detected no anthropogenic impact from bottom trawling despite the precisely georeferenced trawling effort and post-trawling ROV surveys. However, we expect that the time series data on invertebrate communities (both sessile and mobile) collected as part of this project will ultimately enhance our understanding of the ecology of organisms in unconsolidated sediments, including seasonal and interannual variability in the distribution of mobile and epibenthic invertebrates, the patchiness of opportunistic organisms, and interannual variability in invertebrate community structure.

The results of any field research project, as well as the implications of those results, must ultimately be contextualized by a variety of factors. We planned statistical analyses to maximize our chances to capture moderate-to-large effects on trawling metrics. This relatively high statistical power strongly indicates that moderate to large impacts to the metrics that we analyzed would have been detected if they had occurred. However, the very limited impacts of bottom trawling to the seafloor that we observed must be considered in light of 2 primary factors: the use of a small-footrope bottom and the location of the study area in unconsolidated sand sediments.

The small-footrope gear was used at 2 distinct trawling intensities ( 3 and 8 times per trawled plot) that were designed to reflect the low to moderate intensity trawling historically seen in the region off central California (Mason et al., 2012). Yet, with the heterogeneous distribution of trawling effort among fishing vessels, and more specifically, regular focusing of that effort on favored locations that differ among captains, some areas of the seafloor may be impacted more intensively (Auster et al., 1996; Mason et al., 2012). Additionally, much of the historic effort (trawling before the implementation of the federal requirement for small-footrope gear along the continental shelf in 2000) in the study area was prosecuted with a variety of bottom trawls, most of them likely employing larger footrope gear and heavier trawl doors than those on the bottom trawls that we used in our study. As such, the required smallfootrope gear may cause less impact than heavier gear, and therefore the extent to which the lack of impacts that we observed can be extrapolated to other gear types is potentially limited.

Substrate type is also an important factor that must be considered in any extrapolation of the results of our study, as is the behavior of the organisms found in the study area. Our study was located on the outer continental shelf in an area characterized by low-relief, unconsolidated sandy sediments of relatively low diversity (Oliver et al., 2011). We considered the area to be broadly representative of the shelf to the north and south of the study area on the basis of preliminary exploratory surveys completed before this study began and on the basis of additional research that we completed elsewhere along the coast. The additional reference sites that we sampled in May 2012 (Fig. 1) appeared to be similar to the study area with respect to the percent cover of microtopographic features (Fig. 4A). However, the density of sessile invertebrates was higher at the north reference site (Fig. 4B), and the density of mobile invertebrates was higher at both reference sites compared with results in the study area (Fig. 4C). Again, the patchiness in the distribution of organisms on the continental shelf may explain these differences, and organism responses to trawling may also play a role. A study by Troffe et al. (2005) suggested that sea whips of the same genus observed in our study may have the ability to rebound after being knocked over by a passing bottom trawl; however, 
Malecha and Stone (2009) found that recovery of sea whips damaged by trawling was limited.

We focused on the potential impacts of bottom trawling with small-footrope gear on fish habitat on the seafloor off central California. In the context of ongoing efforts to understand and manage fishing impacts (Dinmore et al., 2003; Hannah, 2003; Bellman et al., 2005; Ellis et al., 2008; Hourigan, 2009; de Juan and Lieonart, 2010), the results of our study indicate that bottom trawling with small-footrope gear may have limited impacts in sandy habitats of the outer continental shelf in California. Although the global literature clearly indicates that communities on hard substrates are more vulnerable to bottom trawling (see reviews in Dayton et al., 1995; Kaiser et al., 1998; Watling and Norse, 1998; NRC, 2002; Barnes and Thomas, 2005), the lack of impacts to unconsolidated sandy sediments at a depth of $170 \mathrm{~m}$ as observed in this study indicates that this type of sediment is much less vulnerable, at least at the level of fishing effort undertaken for this study with a bottom trawl that met the federal requirement of a small footrope $(\leq 20 \mathrm{~cm}$ in diameter). Identification of habitats and depth zones appropriate for bottom trawling in the "working seascape" among closed areas will be important for efforts to balance regulations of local seafood and fish landings and the needs of fishermen's livelihoods with environmental impacts of trawling across the continental shelf and slope habitats.

\section{Acknowledgments}

Generous support for this project was provided by the California Ocean Protection Council through a State Coastal Conservancy Grant to The Nature Conservancy (SCC grant no. 10-058), private donations from the Kabcenell Family Foundation and the Seaver Institute, and contributions from the James W. Rote Professorship and the Undergraduate Research Opportunities Center at California State University Monterey Bay. We thank the many students who participated throughout this study (including J. Derbonne, who passed away before the completion of the project). For key support in the field, we recognize the captains and crews of the FV Donna Kathleen, FV South Bay, and RV Fulmar and the ROV team from Marine Applied Research and Exploration. We also thank staff from NOAA Fisheries, the West Coast Groundfish Observer Program, and the Morro Bay Harbormaster's Office. Suggestions provided by 3 anonymous reviewers improved the manuscript.

\section{Literature cited}

Allen, J. I., S. D. Archer, J. C. Blackford, F. J. Gilbert, and A. H. Taylor.

2006. Changes in DMS production and flux in relation to decadal shifts in oceanic circulation. Tellus 58B:242254. doi: 10.1111/ j.1600-0889.2006.00183.x.
Althaus, F., A. Williams, T. A. Schlacher, R. J. Kloser, M. A. Green, B.A. Barker, N. J. Bax, P. Brodie, and M. A. Schlacher-Hoenlinger.

2009. Impacts of bottom trawling on deep-coral ecosystems of seamounts are long-lasting. Mar. Ecol. Prog. Ser. 379:279-294. doi: 10.3354/meps08248.

Alverson, D. L., M. H. Freeberg, S. A. Murawski, and J. G. Pope.

1994. A global assessment of fisheries bycatch and discards. FAO Fish. Tech. Pap. 339, 233 p. FAO, Rome.

Anderson, O. F., and M. R. Clark.

2003. Analysis of bycatch in the fishery for orange roughy, Hoplostethus atlanticus, on the South Tasman Rise. Mar. Freshw. Res. 54:643-652.

Atkinson, L. J., J. G. Field, and L. Hutchings.

2011. Effects of demersal trawling along the west coast of southern Africa: multivariate analysis of benthic assemblages. Mar. Ecol. Prog. Ser. 430:241-255. doi: 10.3354/meps08956.

Auster, P. J., and R. W. Langton.

1999. The effects of fishing on fish habitat. Am. Fish. Soc. Symp. 22:150-187.

Auster, P. J., J. Lindholm, S. Schaub, G. Funnell, L. S. Kaufman, and P. C. Valentine.

2003a. Use of sand wave habitats by silver hake. J. Fish Biol. 62:143-152. doi: 10.1046/j.1095-8649. 2003.00016.x.

Auster, P. J., J. Lindholm, and P. C. Valentine.

2003b. Variation in habitat use by juvenile Acadian redfish, Sebastes fasciatus. Environ. Biol. Fish. 68:381389. doi: 10.1023/B:EBFI.0000005751.30906.d5.

Auster, P. J., R. J. Malatesta, and C. L. S. Donaldson.

1997. Distributional responses to small-scale habitat variability by early juvenile silver hake, Merluccius bilinearis. Environ. Biol. Fish. 50:195-200. doi: 10.1023/A:1007305628035.

Auster, P. J., R. J. Malatesta, R. W. Langton, L. Watling, P. C. Valentine, C. L. S. Donaldson, E. W. Langton, A. N. Shepard, and W. G. Babb.

1996. The impacts of mobile fishing gear on seafloor habitats in the gulf of Maine (Northwest Atlantic): implications for conservation of fish populations. Rev. Fish. Sci. 4:185-202. doi: 10.1080/10641269609388584.

Auster, P. J., R. J. Malatesta, and S.C. LaRosa.

1995. Patterns of microhabitat utilization by mobile megafauna on the southern New England (USA) continental shelf and slope. Mar. Ecol. Prog. Ser. 127:7785. doi: 10.3354/meps 127077 .

Auster, P. J., R. J. Malatesta, S. C. LaRosa, R. A. Cooper, and L. L. Stewart.

1991. Microhabitat utilization by the megafaunal assemblage at a low relief outer continental shelf site-Middle Atlantic Bight, USA. J. Northwest Atl. Fish. Sci. 11:59-69.

Baillon, S., J-F. Hamel, V. E. Wareham, and A. Mercier.

2012. Deep cold-water corals as nurseries for fish larvae. Front. Ecol. Environ. 10:351-356. Auster, P. J., R. J. Malatesta, and S. C. LaRosa.

1995. Patterns of microhabitat utilization by mobile megafauna on the southern New England (USA) continental shelf and slope. Mar. Ecol. Prog. Ser. 127:7785. doi: 10.1890/120022.

Barnes, P. W., and J. P. Thomas, editors.

2005. Benthic habitats and the effects of fishing, 890 p. Am. Fish. Soc. Symp. 41, Bethesda, MD. 
Bellman, M. A., S. A. Heppell, and C. Goldfinger.

2005. Evaluation of a US west coast groundfish habitat conservation regulation via analysis of spatial and temporal patterns of trawl fishing effort. Can. J. Fish. Aquat. Sci. 62:2886-2900. doi: 10.1139/f05-180.

Brodeur, R. D.

2001. Habitat-specific distribution of Pacific ocean perch (Sebastes alutus) in Pribilof Canyon, Bering Sea. Cont. Shelf Res. 21:207-224. doi: 10.1016/ S0278-4343(00)00083-2.

California State Legislature.

2004. Fishing: trawl nets. An act to amend Sections 8495 and 8842 of, to add Sections 8841 and 8494 to, and to repeal Section 8836.5 of, the Fish and Game Code, relating to fishing. S.B. 1459, Chapter 721 (Cal. Stat. 2004). [Available from http://www.leginfo.ca.gov/pub/03-04/bill/sen/sb_1451-1500/sb_1459_ bill_20040923_chaptered.html.]

Collie, J. S., G. A. Escanero, and P. C. Valentine.

1997. Effects of bottom fishing on the benthic megafauna of Georges Bank. Mar. Ecol. Prog. Ser. 155:159172. doi: 10.3354/meps155159.

Connell, J. H., and M. J. Keough.

1985. Disturbance and patch dynamics of subtidal marine animals on hard substrata. In The ecology of natural disturbance and patch dynamics (S. T. A. Pickett and P. S. White, eds.), p.125-147. Academic Press, San Diego, CA.

Copps, S. L., M. M. Yoklavich, G. B. Parkes, W. W. Wakefield, A. Bailey, H. G. Greene, C. Goldfinger, and R. W. Burn.

2008. Applying marine habitat data to fishery management on the US west coast: initiating a policy-science feedback loop, In Mapping the seafloor for habitat characterization. GAC Spec. Pap. 47 (B. J. Todd and H. G. Greene, eds.), p. 451-462. Geol. Assoc. Canada, St John's, Newfoundland.

Dalton, P. D.

1999. Magnuson-Stevens Act provision; foreign fishing; fisheries off West Coast states and in the Western Pacific; Pacific coast groundfish fishery; annual specifications and management measures. Fed. Registr. 65(2):221-249.

Davis, A. C. D., R. G. Kvitek, C. B. A. Mueller, M. A. Young, C.

D. Storlazzi, and E. L. Phillips.

2013. Distribution and abundance of rippled scour depressions along the California coast. Cont. Shelf Res. 69: 88-100. doi: 10.1016/j.csr.2013.09.010.

Dayton, P. K., S. F. Thrush, M. T. Agardy, and R. J. Hofman. 1995. Environmental effects of marine fishing. Aquat. Conserv.: Mar. Freshwat. Ecosyst. 5:205-232. doi: 10.1002/aqc.3270050305.

De Alteris, J. T., L. G. Skrobe, and K. M. Castro.

2000. Effects of mobile bottom fishing gear on biodiversity and habitat in offshore New England waters. Northeast. Nat. 7:379-394. doi: 10.1656/1092-6194(2000)007[0379:EOMBFG]2.0.CO;2.

de Juan, S., and J. Lieonart.

2010. A conceptual framework for the protection of vulnerable habitats impacted by fishing activities in the Mediterranean high seas. Ocean Coast. Manage. 53:717-723. doi: 10.1016/j.ocecoaman.2010.10.005.

de Marignac, J. J. Hyland, J. Lindholm, A. DeVogelaere, W. L.

Balthis, and D. Kline.

2009. A comparison of seafloor habitats and associated benthic fauna in areas open and closed to bot- tom trawling along the central California continental shelf. NOAA Mar. Sanctuaries Conserv. Ser. ONMS-09$02,44 \mathrm{p}$.

Dinmore, T. A., D. E. Duplisea, B. D. Rackham, D. L. Maxwell, and S. Jennings.

2003. Impact of a large-scale area closure on patterns of fishing disturbance and the consequences for benthic communities. ICES J. Mar. Sci. 60:371-380. doi: 10.1016/S1054-3139(03)00010-9.

Ellis N., F. Pantus, A. Welna, and A. Butler.

2008. Evaluating ecosystem-based management options: effects of trawling in Torres Strait, Australia. Cont. Shelf Res. 28:2324-2338. doi: 10.1016/j.csr.2008.03.031.

Engel, J., and R. Kvitek.

1998. Effects of otter trawling on a benthic community in Monterey Bay National Marine Sanctuary. Conserv. Biol. 12:1204-1214. doi: 10.1046/j.1523-1739. 1998.0120061204.x.

Freese, L., P. J. Auster, J. Heifetz, and B. L. Wing.

1999. Effects of trawling on seafloor habitat and associated invertebrate taxa in the Gulf of Alaska. Mar. Ecol. Prog. Ser. 182:119-126. doi: 10.3354/meps182119.

Friedlander, A. M., G. W. Boehlert, M. E. Field, J. E. Mason, J.

V. Gardner, and P. Dartnell.

1999. Sidescan-sonar mapping of benthic trawl marks on the shelf and slope off Eureka, California. Fish. Bull. 97:786-801.

Gerstner, C. L.

1998. Use of substratum ripples for flow refuging by Atlantic cod, Gadus morhua. Environ. Biol. Fish. 51:455460. doi: 10.1023/A:1007449630601.

Gerstner, C. L., and P. W. Webb.

1998. The station-holding performance of plaice, Pleuronectes platessa, on artificial substratum ripples. Can. J. Zool. 76:260-268. doi: 10.1139/z97-192.

Gleason M., C. Cook, M. Bell, and E. Feller.

2009. Are we missing the boat? Collaborative solutions for North American fish wars. Conserv. Biol. 23:10651067. doi: 0.1111/j.1523-1739.2009.01315.x.

Gleason, M., E. M. Feller, M. Merrifield, S. Copps, R. Fujita, M. Bell, S. Rienecke, and C. Cook.

2013. A transactional and collaborative approach to reducing effects of bottom trawling. Conserv. Biol. 27:470-479. doi: 10.1111/cobi.12041.

Hall, S. J.

1994. Physical disturbance and marine benthic communities: life in unconsolidated sediments. Oceanogr. Mar. Biol. Annu. Rev. 32:179-239.

Hallenbeck, T. R., R. G. Kvitek, and J. Lindholm.

2012. Rippled scour depressions add ecologically significant heterogeneity to soft-bottom habitats on the continental shelf. Mar. Ecol. Prog. Ser. 468:119-133. doi: 10.3354/meps09948.

Hannah, R. W.

2003. Spatial changes in trawl fishing effort in response to footrope diameter restrictions in the U.S. west coast bottom trawl fishery. N. Am. J. Fish. Manage. 23:693702. doi: 10.1577/M02-098.

Henry, L-A, E. L. R. Kenchington, T. J. Kenchington, K. G. MacIsaac, C. Bourbonnais-Boyce, and D. C. Gordon.

2006. Impacts of otter trawling on colonial epifaunal assemblages on a cobble bottom ecosystem on Western Bank (northwest Atlantic). Mar. Ecol. Prog. Ser. 306:63-78. doi: 10.3354/meps306063. 
Hiddink, J. G., S. Jennings, M. J. Kaiser, A. M. Queiros, D. E. Duplisea, and G. J. Piet.

2006. Cumulative impacts of seabed trawl disturbance on benthic biomass, production,

and species richness in different habitats. Can. J. Fish. Aquat. Sci. 63:721-736. doi: 10.1139/f05-266.

Hiddink, J. G., S. Jennings, and M. J. Kaiser.

2007. Assessing and predicting the relative ecological impacts of disturbance on habitats with different sensitivities. J. Appl. Ecol. 44:405-413. doi: 0.1111/j.1365-2664.2007.01274.x.

Hilborn, R., I. J. Stewart, T. A. Branch, and O. P. Jensen.

2012. Defining trade-offs among conservation, profitability, and food security in the California Current bottom-trawl fishery. Conserv. Biol. 26:257-266. doi: 10.1111/j.1523-1739.2011.01800.x.

Hixon, M. A., and B. N. Tissot.

2007. Comparison of trawled vs. untrawled mud seafloor assemblages of fishes and macroinvertebrates at Coquille Bank, Oregon. J. Exp. Mar. Biol. Ecol. 344:2334. doi: 10.1016/j.jembe.2006.12.026.

Hourigan, T. F.

2009. Managing fishery impacts on deep-water coral ecosystems of the USA: emerging best practices. Mar. Ecol. Prog. Ser. 397:333-340. doi: 10.3354/meps08278.

Hurlbert, S. H.

1984. Pseudoreplication and the design of ecological field experiments. Ecol. Monogr. 54:187-211. doi: $10.2307 / 1942661$.

Jackson, J. B. C., M. X. Kirby, W. H. Berger, K. A. Bjorndal, L. W. Botsford, B. J. Bourque, R. H. Bradbury, R. Cooke, J. Erlandson, J. A. Estes, T. P. Hughes, S. Kidwell, C. B. Lange, H. S. Lenihan, J. M. Pandolfi, C. H. Peterson, R. S. Steneck, M. J. Tegner, and R. R. Warner.

2001. Historical overfishing and the recent collapse of coastal ecosystems. Science 293:629-637. doi: 10.1126/science.1059199.

Kaiser, M. J., and B. E. Spencer.

1994. Fish scavenging behavior in recently trawled areas. Mar. Ecol. Prog. Ser. 112:41-49.

Kaiser, M. J., J. S. Collie, S. J. Hall, S. Jennings, and I. R. Poiner.

2002. Modification of marine habitats by trawling activities: prognosis and solutions. Fish Fish. 3:114-136. doi: 10.1046/j.1467-2979.2002.00079.x.

Kaiser, M. J., D. B. Edwards, P. J. Armstrong, K. Radford, N.

E. L. Lough, R. P. Flatt, and H. D. Jones.

1998. Changes in megafaunal benthic communities in different habitats after trawling disturbance. ICES J. Mar. Sci. 55:353-361. doi: 10.1006/jmsc.1997.0322.

Kaiser, M. J., K. Ramsay, C. A. Richardson, F. E. Spence, and

A. R. Brand.

2000. Chronic fishing disturbance has changed shelf sea benthic community structure. J. Anim. Ecol. 69:494503. doi: 10.1046/j.1365-2656.2000.00412.x.

Kitaguchi, B. D.

2011. Benthic community structure in trawled and untrawled areas of the outer continental shelf. M.S. thesis, 114 p. San Jose State Univ., San Jose, CA.

Koslow, J. A., K. Gowlett-Holmes, J. K. Lowry, T. O’Hara, G. C. B. Poore, and A. Williams.

2001. Seamount benthic macrofauna off southern Tasmania: community structure and impacts of trawling. Mar. Ecol. Prog. Ser. 213:111-125. doi: 10.3354/ meps213111.
Lindholm, J. B., P. J. Auster, and L. S. Kaufman.

1999. Habitat-mediated survivorship of juvenile (0-year) Atlantic cod Gadus morhua. Mar. Ecol. Prog. Ser. 180:247-255. doi: 10.3354/meps180247.

Lindholm, J. B., P. J. Auster, M. Ruth, and L. Kaufman.

2001. Modeling the effects of fishing and implications for the design of marine protected areas: juvenile fish responses to variations in seafloor habitat. Conserv. Biol. 15:424-437. doi: 10.1046/j. 1523-1739.2001.015002424.x.

Lindholm, J., P. Auster, and P. Valentine.

2004. Role of a large marine protected area for conserving landscape attributes of sand habitats on Georges Bank (NW Atlantic). Mar. Ecol. Prog. Ser. 269:61-68. doi: 10.3354/meps269061.

Lindholm, J., M. Kelly, D. Kline, and J. de Marignac.

2009. Patterns in the local distribution of the sea whip (Halipteris willemoesi), in an area impacted by mobile fishing gear. Mar. Technol. Soc. J. 42:64-68. doi: $10.4031 / 002533208787157651$.

Lipsey, M.

1990. Design sensitivity: statistical power for experimental research, 207 p. Sage Publications, Newbury Park, CA.

Lohrer, A. M., S. F. Thrush, and M. M. Gibbs.

2004. Bioturbators enhance ecosystem function through complex biogeochemical interactions. Nature 431:1092-1095. doi: 10.1038/nature03042.

Machias, A., V. Vassilopoulou, D. Vatsos, P. Bekas, A. Kallianiotis, C. Papaconstantinou, and N. Tsimenides.

2001. Bottom trawl discards in the northeastern Mediterranean Sea. Fish. Res. 53:181-195. doi: 10.1016/ S0165-7836(00)00298-8.

Malatesta, R. J., and P. J. Auster.

1999. The importance of habitat features in low-relief continental shelf environments. Oceanol. Acta 22:623626. doi: 10.1016/S0399-1784(00)88953-7.

Malecha, P. W., and R. P. Stone.

2009. Response of the sea whip Halipterus willomoesi to simulated trawl disturbance and its vulnerability to subsequent predation. Mar. Ecol. Prog. Ser. 388:197206. doi: 10.3354/meps08145.

Mason, J., R. Kosaka, A. Mamula, and C. Speir.

2012. Effort changes around a marine reserve: the case of the California Rockfish Conservation Area. Mar. Policy 36:1054-1063. doi: 10.1016/j.marpol.2012.03.002.

McConnaughey, R. A., K. L. Mier, and C. B. Drew.

2000. An examination of chronic trawling effects on soft-bottom benthos of the eastern Bering Sea. ICES J. Mar. Sci. 57:1377-1388. doi: 10.1006/jmsc.2000.0906.

Meysman, F. J. R., J. J. Middelburg, and C. H. R. Heip.

2006. Bioturbation: a fresh look at Darwin's last idea. Trends Ecol. Evol.21:688-695. doi: 10.1016/j. tree.2006.08.002.

Morrisey, D. J., L. Howitt, A. J. Underwood, and J. S. Stark. 1992. Spatial variation in soft-sediment benthos. Mar. Ecol. Prog. Ser. 81:197-204.

NRC (National Research Council).

1999. Sustaining marine fisheries, 164 p. National Academies Press, Washington, D.C.

2002. Effects of trawling and dredging on seafloor habitat, 126 p. National Academy Press, Washington, D.C. 
Oliver, J., K. Hammerstrom, E. McPhee-Shaw, P. Slattery, J. Oakden, S. Kim, and S. I. Hartwell.

2011. High species density patterns in macrofaunal invertebrate communities in the marine benthos. Mar. Ecol. 32:278-288. doi: 10.1111/j.1439-0485.2011.00461.x.

Pitcher, C. R., C. Y. Burridge, T. J. Wassenberg, B. J. Hill, and

I. R. Poiner.

2009. A large scale BACI experiment to test the effects of prawn trawling on seabed biota in a closed area of the Great Barrier Reef Marine Park, Australia. Fish. Res. 99:168-183. doi: 10.1016/j.fishres.2009.05.017.

$\mathrm{R}$ Core Team.

2014. R: a language and environment for statistical computing. R Foundation for Statistical Computing, Vienna, Austria. [Available from http://www.R-project.org/.]

Reiss, H., S. P. R. Greenstreet, K. Sieben, S. Ehrich, G. J. Piet,

F. Quirijns, L. Robinson, W. J. Wolff, and I. Kröncke.

2009. Effects of fishing distrubance on benthic communities and secondary production within an intensively fished area. Mar. Ecol. Prog. Ser. 394:201-213. doi: 10.3354/meps08243.

Rooper, C. N., M. E. Wilkins, C. S. Rose, and C. Coon.

2011. Modeling the impacts of bottom trawling and the subsequent recovery rates of sponges and corals in the Aleutian Islands, Alaska. Cont. Shelf Res. 31:18271834. doi: 10.1016/j.csr.2011.08.003.

Sanchez, P., M. Demestre, M. Ramon, and M. J. Kaiser.

2000. The impact of otter trawling on mud communities in the northwestern Mediterranean. ICES J. Mar. Sci. 57:1352-1358. doi: 10.1006/jmsc.2000.0928.

Schwinghamer, P., D. C. Gordon, Jr., T. W. Rowell, J. Prena, D.

L. McKeown, G. Sonnichsen, and J. Y. Guigné.

1998. Effects of experimental otter trawling on surficial sediment properties of a sandy-bottom ecosystem on the Grand Banks of Newfoundland. Conserv.
Biol. 12:1215-1222. doi: 10.1046/j.1523-1739.1998. 0120061215.

Shephard S, C. A. Goudey, A. Read, and M. J. Kaiser.

2009. Hydrodredge: reducing the negative impacts of scallop dredging. Fish. Res. 95:206-209.

Stone, R. P.

2006. Coral habitat in the Aleutian Islands of Alaska: depth distribution, fine-scale species associations, and fisheries interactions. Coral Reefs 25:229-238. doi: 10.1007/s00338-006-0091-z.

Stoner, A. W. and R. H. Titgen.

2003. Biological structures and bottom type influence habitat choices made by Alaska flatfishes. J. Exp. Mar. Biol. Ecol. 292:43-59. doi: 10.1016/S0022-0981(03) 00144-8.

Tissot, B. N., M. M. Yoklavich, M. S. Love, K. York, and M. Amend.

2006. Benthic invertebrates that form habitat on deep banks off southern California, with special reference to deep sea coral. Fish. Bull. 104:167-181.

Troffe, P. M., C. D. Levings, G. E. Piercey, and V. Keong.

2005. Fishing gear effects and ecology of the sea whip (Halipteris willemoesi (Cnidaria: Octocorallia: Pennatulacea)) in British Columbia, Canada: preliminary observations. Aquat. Conserv.: Mar. Freshwat. Ecosyst. 15:523-533. doi: 10.1002/aqc.685.

Tupper, M. and R.G. Boutilier.

1995. Effects of habitat on settlement, growth, and postsettlement survival of Atlantic cod (Gadus morhua). Can. J. Fish. Aquat. Sci. 52: 1834-1841. doi: 10.1139/f95-176.

Watling, L., and E. A. Norse.

1998. Disturbance of the seabed by mobile fishing gear: a comparison to forest clearcutting. Conserv. Biol. 12:1180-1197. doi: 10.1046/j.1523-1739.1998. 0120061180.x. 